\title{
The Golkar's Structures and Political Interaction Changes (Study on The Golkar Party in Bandung, Indonesia)
}

\author{
Pipin Hanapiah \\ Department of Government Science, Padjadjaran University, Bandung, Indonesia \\ pipin_hanapiah@yahoo.com
}

\begin{abstract}
Each political party will be changed because it is determined by its internal and external factors. The changes are ongoing at their political process and mechanism, towards their objective and gives an impact to environment both to internally and externally. The change occured on Golkar's structures and political changes in facing national reformation movement. Research affords to describe the changes that have been going on, through external dan internal determinants, process and mechanism, as well as the objective and impact. The research object is Golkar's structures and political interaction that changed at the Golkar party in Bandung. The research used political sociology studies, qualitative approach, and descriptive methods. Meanwhile, the techniques of collecting data used document, literature, observation, and in-depth interview with using resource triangulation. The result of research showed Golkar faces process and mechanism changes, particularly about political structures and interaction. It determined by external (national reformation movement) and internal (democracy demand) factors. It leads to objective (adapting, modernizing, democratic, and decentralization) and impacts (to the Indonesian armed forces retired members and the civil servant and also the people to make and manage new political parties). To modernize its structure and political interaction, Golkar in Bandung should be continue the commitment, consistency, and adaptation to the nation development and dynamic of the region in Bandung.
\end{abstract}

\section{Keywords: Political changes, political party, golkar.}

\section{Introduction}

Since it was established and development, Golkar often changing its structural and political interaction. Golkar was a political party in the Reformation Era which most likely thought to have the biggest changes in its structures. This study is limited to structure and political interactions changes from 'Old Golkar' to 'New Golkar'. This is due to external and internal factors within Golkar. Structurally, the Golkar organization had ranging levels from The Central Executive Board located in the Center (Jakarta), the Regional Representative Council I, located in every province, and the Regional Representative Council II located in each district/city. This study was conducted based on consideration that the changes of Golkar's structures and political interaction occured at every organization levels, both at the level Central Executive Board, Regional Representative Council I, Regional Representative Council II, as well as at the district and even villages. Thus, structurally Golkar political changes occurred also in Bandung. Bandung was chosen based on the consideration: (a) The capital of west java province, Bandung regarded as a representation of the cultural city-cities located in the middle of the culture-urban-metropolitan and cultures-rural, (b) Bandung, city of education, government, commerce, tourism, and so on is considered as a growing representation cityegalitarian-parochial political cultures, among the egalitarian-participatory culture and patrimonial-servant political culture, and (c) Bandung included as one of the cities that have mass-wishers voting for Golkar in every election (general election) which have a relatively stable and continuous amounts for the legislature (House of Representative, Regional Representative Assembly of West Java Province, and Regional Representative Assembly in Bandung).

The Golkar's political structures changes-particularly in the reformation era is a changes planned and programmed to achieve changes objectives expected by state. Therefore, Golkar ability to change itself, both to process and political mechanism, assigned by determinant changes, which are external and internal factors. Both of these factors are interrelated and reinforce. This process and mechanism determines the 
political direction (objectives) and impact (consequences) at national, regional, provincial, and district / city level, including Bandung. Based on these problems, the question are :

- How is the internal and external determinants assign the Golkar's structures and political interaction changes in Bandung?

- How is the proccess and mechanism of the Golkar's structures and political interaction changes in Bandung?

- How is the direction and impact of the Golkar's structures and political interaction changes in Bandung?

\section{Literature Review}

Sorokin (in Lauer, 1993) as expressed also by Smelser and Haferkamp-put forward three possible explanations regarding sociocultural changes. First, the change may be due to external factors. Second, changes occur due to internal factors. Third, finding causes of changes in both external and internal factors. More further, Haferkamp and Smelser (1992) put forward about 3 things needed to analyze the social changes issues, namely the existence of (a) structural determinant-determinant or factor that cause social changes; (b) process and mechanism of social changes; and (c) direction and impact of social changes. Koentjaraningrat (1990) more detailing changes which included the mechanism (issues) related to the form and rules of social organization, values, norms, rules, activities, and actions. The changing pattern of interaction is a change in action-reaction differentiated pattern into four kinds, namely cooperation, competition, contention, and accommodation. The political changes direction (objectives) as assessed by Huntington (in Susanto) can be modernization, democratization, decentralization, and so on. Through the models, Jones and Buzan (in Susanto and Djafar, 1990) states that in order to describe and analyze a changes needed three concepts/the structural phase elements, namely that the changes (1) has a tendency (process), (2) follow the objectives (direction) needs that is practical and can be reached usefullness, and (3) empirically perceived the impact / consequences.

Thus, the structures and political parties interaction changes includes changes in mechanisms associated with the Golkar's organizational form, organizational regulations, a value of (paradigm and vision) organization, norms (ethics) organization, activity (missions and programs) organization, and action (policy and technique). In addition, changes in political parties will appear also in the politics process (interaction patterns or tendencies). Changes in interaction political parties process is a change in action and reaction pattern from the parties to environment (both internal and external) that may be done by altering cooperation, competition, conflict, or political accommodation pattern. Therefore, according to Blondel (1995), this kind of political interaction refers to bargaining, negotiations, discussions, and so forth about the political interests from both parties to be decided by the possesor as political authority holder. External factors, could be a government policy, challenges from other political parties, non-community sympathizers of Golkar,mass media, or others. While factors that come from internal of Golkar could be a change in the sympathizers aspirations, wings/kino-kino, administrators and elite, or others.

\section{Methodology}

The object of this study is the Golkar's structures and political interaction in Bandung. This study use a descriptive method with qualitative approach. The study using analysis changes of Sorokin, Smelser, and Haferkamp, with a weld because it is more suitable to the problem, namely the phenomenon of Golkar's structures and political interaction changes which divided into three major dimensions: structural determinant, proccess and mechanism, as well as the direction and impact.

Table 1: Analysis of Golkar's structures and political interaction

\begin{tabular}{|c|c|c|c|}
\hline Dimension & Aspect & Operasional Conception & tor (Conception Details) \\
\hline $\begin{array}{l}\text { Structural } \\
\text { Determinant }\end{array}$ & $\begin{array}{l}\text { External } \\
\text { Factors }\end{array}$ & $\begin{array}{l}\text { This aspect related with external factors } \\
\text { which determined Golkar's political } \\
\text { changes in Bandung }\end{array}$ & $\begin{array}{l}\text { * Reformation Movement } \\
\text { * Chairman of The Board } \\
\text { UUD } 1945 \text { amendment } \\
\text { Constitution }\end{array}$ \\
\hline
\end{tabular}




\begin{tabular}{|c|c|c|c|}
\hline Dimension & Aspect & Operasional Conception & Indicator (Conception Details) \\
\hline \multirow{18}{*}{$\begin{array}{l}\text { Process } \\
\text { and } \\
\text { Mechanism }\end{array}$} & & & Constitutional Court Decision \\
\hline & & & Society Assertion \\
\hline & & & Democratization Assertion \\
\hline & & This aspect related with internal factors & Desentralization Assertion \\
\hline & $\begin{array}{l}\text { Internal } \\
\text { Factors }\end{array}$ & which determined Golkar's political & Akbar Tanjung's Breakthrough \\
\hline & & changes in Bandung & $\begin{array}{l}\text { Yusuf Kalla's Leadership } \\
\text { The seats in Bandung's Parliament }\end{array}$ \\
\hline & & & ${ }^{k}$ Elite's power decentralization \\
\hline & & This aspect subtances to Golkar's & ${ }^{k}$ Political orientation support \\
\hline & Process & political interaction both eksternally and & ${ }^{k}$ Government Negotiation \\
\hline & & internally & ${ }^{k}$ Parties/factions coalition \\
\hline & & & $\begin{array}{l}\text { Paradigm, name, and Golkar's } \\
\text { organizational form }\end{array}$ \\
\hline & & This aspect subtances to Golkar's & Golkar's vision \\
\hline & & political structure changes related to & Golkar's platform \\
\hline & Mechanism & organization & $\begin{array}{l}\text { Golkar's mision } \\
\text { Golkar's policy }\end{array}$ \\
\hline & & & Golkar's programm \\
\hline & & & Method/technique/ politik way \\
\hline & & & Golkar's strugle doctrine \\
\hline & & & $\begin{array}{l}\text { Norm or Golkar's political ethic } \\
\text { Golkar's adaptation }\end{array}$ \\
\hline \multirow{7}{*}{$\begin{array}{l}\text { Direction } \\
\text { and } \\
\text { Impact }\end{array}$} & & This aspect related with the objectives of & Golkar's modernization \\
\hline & Direction & Golkar's political changes & Golkar's democratization \\
\hline & & & $\begin{array}{l}\text { Golkar's desentralization } \\
*\end{array}$ \\
\hline & & & The spread of retired military / \\
\hline & & & $\begin{array}{l}\text { police and retired civil servants in } \\
\text { other political parties }\end{array}$ \\
\hline & Impact & $\begin{array}{l}\text { This aspect related with the } \\
\text { consequences of Golkar's political }\end{array}$ & Public participation in a variety of \\
\hline & & & $\begin{array}{l}\text { partner determination coalition } \\
\text { cadre / Executive candidate } \\
\text { (Mayor / Vice Mayor) }\end{array}$ \\
\hline
\end{tabular}

The data collection through indeepth interview techniques (indepth-interview) to the base and main informant, observation or direct observation, and documentation study to validate sources through triangulation techniques.

\section{Results and Discussion}

Organizational structurally, Golkar's structural changes in Bandung is a 'copy-paste' political structural changes that occur in Golkar party nationally. This is understandable because the Golkar party in Bandung is a part and in organizational structure vertically upwards which lead to the Central Executive Board. Likewise, changes in political structures of Golkar party in Bandung, organizational structurally will affect the bottom which disembogue on Golkar Party Village Board in Bandung.

External and Internal Determinant: External factors, the first, which assign changes in Golkar's political structures is society assertion and political reformation movements, spearheaded by scholars and youth which occured continuously and massive post-election 1997 until May 1998. The most fundamental reformation assertion is declining the Great General (ret.) Suharto from President of the Indonesian republic 
for not being able to cope financial crisis that affected economic and national leadership crisis. This movement is enlarged and strengthened when the national figures (such as KH Abdurrahman Wahid, Prof. Dr. Amien Rais, Sri Sultan Hamengkubuwono X, and Megawati Soekarnoputri) and other political elites participate in politics. They give support to the scholars movement and put pressure on President Suharto to resign from his position. This is a second external factors. The movement culminated in leadership appeal of MPR/DPR to President Suharto to resign as President. The third external factors is hardened when almost all those who are outside the "circle-loyal 'to Pak Harto, including those who originally sided with him-that is among private ones (no capacity to represent institutional) in the Golkar Family circle--, participate pressing and turn-direction become pro-reform movement. This is the fourth factor. The fourth external determinants led to the resignation of President Suharto from his position on May 21, 1998.

In addition, other external factors, the fifth,is the UUD 1945 changes (as much as four times changes through the Plenary Assembly meeting as a legislative elections result of 1999, the Amendment I (1999), Amendment II (2000), Amendment III (2001) and Amendment IV (2002). The sixth, the determinant legislation factors (the Act), especially concerning political parties and elections. In these Act both revealed substance to strengthen and uphold the fourth mandate of amendment to the Constitution of 1945. It is also substainces the people's sovereignty embodiment as a means to produce a democratic governments. Two legislation are interrelated because the election participants, especially to elect members of the representative council and regional representative assembly, are political parties. So both were like 'two currencies in the same coin', namely the Legislation on Political Parties and Legislative Elections. Both regulations jointly and mutually reinforcing the external factors that assign Golkar's political changes, including the Golkar political changes in Bandung. Some of the Constitutional Court associated with the political parties life, namely the one that was last time in the Constitutional Court form ruling dated December 23, 2008 related with materials submitted several political parties and individuals test against Article 214 of Legislation Number 10 Year 2008 regarding the General Election of the representative council, Regional Representative Council, and Regional respresentative Assembly which contents are 'cancellation usage sequence number system in determining legislative candidates' be by majority vote'. Consideration of constitutional court's decision due to the substance of election was basically a people's sovereignty through the voters sovereignty is not a political party rules. It became instantly the seventh external determinant factor.

Internal determinants that visiblly assign changes in the political structures of Golkar is the following factors presence :

- Democratization assertion. This assertion has acctually been fought by the young cadres of Golkar since the New order, when pricking issues and corruption, collusion and nepotism practices. The other thing is that because autocratic politics practice structurally under the the trustees chairman board control.

- Desentralization assertion. Along with assertion for democratization, decentralization of power and authority within Golkar is fought for a long time as well. But for same reason, these internal factors foundered too often in the middle of the road.

- Akbar Tandjung's Breakthrough. Internal factors are mainly related to the spirit and movement of Akbar Tanjung that carries and fight 'New Golkar' with the slogan 'Golkar Party with New Paradigm' that disconnection with 'Old Golkar' led to the National Conference of Extraordinary Golkar convening 1998.

- Jusuf Kalla's Models and leadership styles. Yusuf Kalla's model and style of political leadership as Golkar Chairman when has the majority votes/chairs in Parliament from the legislative elections results 2004. In addition, he was backed as a merchant who has been accustomed to pragmatic and tactical as well as bold and swift in exploiting opportunities to take difficult decisions and actions. Both capital and political potential is portrayed as Vice President. Strictly speaking, Golkar party political interaction was changed.

- Number of chairs Regional Representative Assembly Golkar fraction in Bandung. The number of Golkar fraction members/chairs are only 6 person (the 2004 election result) turned out to have decisive political interaction that significantly changed. 
Process dan Mechanism: The results showed that with the 12 determinants, either in the external or internal factors form, have determined the Golkar's structures and political interaction changes. These changes are associated with two things, namely the process and mechanism changes. Generally, Golkar changes marked by the new political parties establishment as a political discord within Golkar. Toward the legislative elections of 2004, this Golkar discord proven by the establishment of Justice and Unity Party which later became Indonesian Justice and Unity Party led by General (Ret.) Edi Sudrajat, Concern for the Nation Functional Party led by General (Ret.) R. Hartono, and Kinship Consultative Parties of the Mutual Cooperation which later became Mutual Cooperation Party led by Hj. Mien Sugandhi. All three participated in the 2004 elections but only get a few sound. Toward and in 2009 legislative elections The Golkar discord still persists, namely the establishment of People's Conscience Party led by General (Ret.) Wiranto and Indonesian Movement Party led by Lt. Gen. (Ret.) Prabowo Subianto. Both parties have passed from the General Election Commission verifying and participated in the 2009 election. When examined, these discordance are more likely commanded by the former high-ranking military (read: The Army) and The Golkar leaders-kino kino (organizations founder) especially Mutual Cooperation Party. Here are easy to read that the discord was the Golkar's structural and political interaction changes military brass demeanour, the one which broke (disconnection) with New Orde.

The Structures and Political Interaction Changes Process: The Golkar's structures and political interaction changes proccess basically is Golkar political changes in interaction pattern (substantially behavior) both in relation inside (internal) or outside (external) Golkar organizations (Party) in Bandung. These internal political interaction include working relationship members, between the board, as well as members and the board both vertically upwards or downwards. External political interactions overwhelm Golkar Party Regional Representative Assembly working relationships with other political parties in Bandung, with the same peer faction in legislative Bandung, and with the government (executive) in Bandung. Golkar extraordinary national congress in 1998 which claimed held in reformation spirit and renewal. Since then, Golkar's political structures changes process occur in many aspects, namely (1) the previous autocratic politics democratization, (2) the power elite of previous centralization decentralization, (3) the mass political support orientation from political support elite previous orientation, (4) political negotiations with the government and political parties / other factions of the previous domination and political hegemony with the government, bureaucracy, and Millitary, (5) a political parties / factions coalition of minorities previous political domination, and (6) controlled by public from previous public control.

Table 2: The Process of Golkar's Political Changes

\begin{tabular}{lll} 
The Process of Golkar's Political Changes in Bandung & \\
Previous & Political Process & Thereafter \\
\hline Autocratic & government pattern & democratic \\
power centralization & power pattern & power decentralization \\
elitist/authority & support orientation & populist/voter \\
KBG (K, B, G way) & influence pattern & $\begin{array}{l}\text { government negotiations } \\
\text { political parties coalition }\end{array}$ \\
domination and hegemony & work legislative pattern & /faction \\
Muted & public control & required/noted \\
\hline
\end{tabular}

The fact that until before extraordinary national congress, Golkar was the majority single-shareholder-in Indonesian political arena, including in Bandung at the time. The political domination happening within Golkar organization itself internally and externally organization in work relations with Construction of United Party and Indonesian Democratic Party, as well as in political system at all structural levels in Indonesia. The presence of Golkar Chairman Board of Trustees determinant factors is a symbol that assign this political process. This political changes process continues and occurred also in Bandung, namely the civilian cadre election to lead Golkar Regional Representative Assembly Bandung in the last two periods (1999-2004 and 2004-2009). Even the majority of its Regional Representative Assembly board members also the Golkar's civilian political cadres. This fact extends to Golkar Board at district level and village in Bandung. Also in the political campaign process for the legislative elections of 2009. Even after the Constitutional Court 
ruling release on legislative members determination in the election based on the most vote than before which based on numerical order, now all candidates should go to citizens in order to gain voters sympathy and voting for them on the elections 2009.

In terms of political support orientation for the Golkar Regional Representative Council boards as well as the candidates and members of Regional Representative Assembly Golkar fraction in Bandung has undergone a change. For the Golkar board candidate, a change occurs from originally used to seek support from Golkar's elites/ officials leaders by means of 'ngadeuheus bari ngesun leungeun' (read: visit and respect to top level) to become leaders/boards into the populist way to approach and lobby members of the Golkar Regional Council. Likewise for legislative candidates, changes occur in an effort to get the number-sequence-so originally determined by the leader become looking for support to voters constituents and/or citizens in a new way election, namely 'mejeng bari garumasep / garumeulis dina tatangkalan disisi-sisi jalan' (read : draw attention). Orientation changes seek to support voters being more lively and vibrant for the Regional Representative Assembly Golkar legislative candidate in Bandung from after the Constitutional Court release ruling on legislative members determination by majority vote which took effect in 2009 legislative elections.

The Structures and Political Interaction Changes Mechanism

Table 3: Mechanism of Golkar's Political Structures Changes

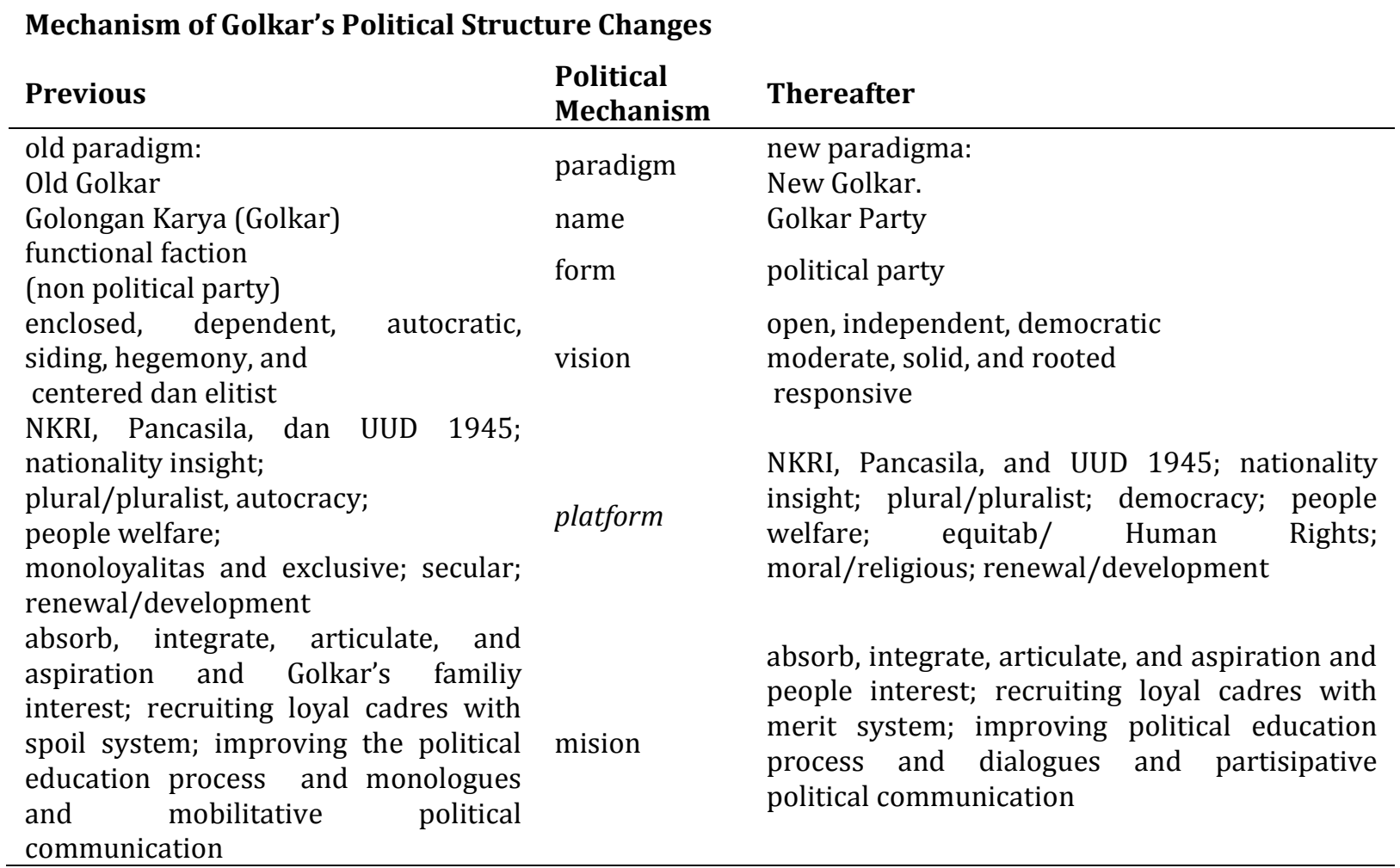


Doctrine, Norm, or Political Ethic

Table 4: Doctrine, Norm, and Political Ethic

\begin{tabular}{lll}
\hline \multicolumn{1}{c}{ Previous } & Political Mechanism & Thereafter \\
\hline Old AD/ART, & & New AD/ART, \\
There is & & none \\
Board of Supervisor & doctrine/ & Board of Supervisor \\
Led by & norm/ & and \\
President Soeharto, & ethic & none \\
and & & 3 way leadership (GF) \\
3 way leadership (GF) & & \\
\hline
\end{tabular}

Method/Technique/Political Way: Based on the study result, Golkar, previously, accustomed to use political method/technique/politic way in (1) dominate, (2) embrace all, (3) enforce, (4) muffle, and (5) acting unilaterally. Now after Golkar change, the method/technique/way also changes, becomes (1) balancing, (2) prioritization, (3) influence, (4) observe, and (5) act on the mutual agreement basis.

Direction and Impact : The results showed that the changes in the structure and the Golkar political interactions process and mechanism, which occur due to external or internal factors, as described above, has given direction and impact for the structure and political interaction changes. The direction and impact is illustrated below.

Direction of Structure and Political Interaction Changes: These direction of Golkar structure and political interaction changes basically is in the emergence of expected political goals and fought form by Golkar Party in Bandung. The political changes direction are more strategic, comprehensive and future-oriented for Golkar Party in the national, regional, and local context. Through the study found four (4) the Golkar political changes direction. First, the Golkar political changes that occurred during the time is intended as an attempt to adapt the Golkar political reform movement in Indonesia that continue rolling at the moment and even to the future. This direction as proven that the Golkar agree, support, and participate in fought and consistently objectify. Second, Golkar political changes direction for modernization. This direction more laying on the status and implementation of the Golkar functions and role as a true political party. Golkar party status that should functioning and contribute to organizing political education, political communication, political recruitment, reliever political conflict, providers and suppliers prospective political leaders, and so on. Status and function and modern role is intended to achieve transparency, accountability, effectivity, and efficiency of Golkar politics in the future. Third direction is to create democratization. Democratization of political parties to adapt internal assertion dynamic and to build quality Golkar Party in the future. This direction is to improve the democracy quality in Indonesia. As known, the democratization is one of a reform agenda which assertioned and fought by the Indonesian nation when this nation autocratically run in the New Orde era along ago. The last direction or political changes aim, fourth, is decentralization. These political decentralization direction is expected by the Golkar party as an ongoing process in the future. At Golkar party in Bandung itself, this direction scrolling continues with hope and optimism.

\section{Structures and Political Interaction Changes Impact}

Table 5: Direction and Political Changes Impact

\begin{tabular}{ll}
$\begin{array}{l}\text { Direction and Golkar's Political Changes Impact } \\
\text { Direction } \\
\text { (aims) }\end{array}$ & $\begin{array}{l}\text { Impact } \\
\text { (consequency) }\end{array}$ \\
\hline adapt with reformation movement & $\begin{array}{l}\text { new political parties proliferation } \\
\text { the spread of retired Armed Forces (TNI/Polri) and retired civil }\end{array}$ \\
Golkar modernization & $\begin{array}{l}\text { servants on political parties } \\
\text { strengthening public participation in political parties } \\
\text { Golkar democratization }\end{array}$ \\
decentralization of Golkar power & factions/others faction \\
\hline
\end{tabular}




\section{Conclusion}

Golkar's structures and political interaction changes occured due to external factors which is (1) national political changes programm planned by the government through the Legislation on Political Party, (2) a policy of neutrality military and bureaucracy from and to political parties, and (3) the party reform assertion of society. All three external factors were amplified by the presence of internal factors such as (1) The resignation of General (ret.) Suharto (The Golkar Chairman Board of trustees), (2) The decentralization and democratization assertion from Golkar internal, (3) Akbar Tanjung figure breakthrough (Chairman of Golkar), and (4) leadership model from Jusuf Kalla Golkar Party Chairman. Since both determinant factors, the Golkar's structures and political interactions in Bandung has changed in (1) the process through erosion of power centralization and candidates cadres emergence based mass support, and (2) the mechanism components such as the culture, structure, group, leadership, and wisdom. Changes in the political process and mechanism of Golkar Party in Bandung led/aims for adaptation, modernization, democratization, and decentralization. This directions/aim give impacts/consequences on the internal arousal democracy Golkar party form among cadres as well as on an external Golkar party in the form of (1) a new political parties proliferation, (2) the spread of the retired military and retired civil servant cadre/political party caretaker, (3) The spirit and political participation community growth to many political parties, and (4) the executive branch determination leadership in Bandung Government through a coalition political parties.

Suggestion: The external determinants structures and political interaction changes existence, Golkar party in Bandung should consider it as a new challenge to improve the image to public, constituents and voters as well as the internal determinants. In addition that become a cadres new spirit who have a sense of ownership and responsibility for the organization's progress. Golkar Party improving needs to be done by internal awareness and enthusiasm rather than influence or assertion from outside parties. Making changes continuously, political processes and mechanisms need to be strengthened both the quality and intensity by Golkar party in Bandung through political policies, programs, attitudes, and behavior as true as a modern, democratic, reformist and populist political parties. The succedd is largely determined by the strength of the public vote sympathy and support in the election. Golkar party need to improve its member/chair faction in Bandung Regional Representative Assembly legislative parliament elections in 2009. Therefore should be used political methods-retailing by Golkar party and the legislative prospective members, absorb the political aspirations of voters as a 'door to door'. The Golkar's structures and political interaction changes direction in form of modernization, democratization, and decentralization needs to be accommodated by the government and appreciated by the public. These third directions would be useful to encourage the process of modernization, democratization, and decentralization in the life of society, nation, and state. The changes impact should also be used by other parties. The release of political ties with the military and bureaucracy would be very beneficial for the strengthening and improvement of democratic Indonesia. The political structures release of this bond should be followed up by Golkar party into a democratic political interaction for each investigator, members, cadres and managers.

\section{References}

Blondel, J. (1995). Comparative Government: An Introduction (2 $2^{\text {nd }}$ edition), Prentice-Hall/ Harvester Wheatsheaf, London.

Haferkamp, H. \& Smelser, N. J. (1992). Social Change and Modernity, University of California Press, Berkeley. Koentjaraningrat. (1990). Manusia dan Kebudayaan di Indonesia, Gramedia, Jakarta.

Lauer, R. H. (1993). Perspektif tentang Perubahan Sosial (Translated by Alimandan from the original book Perspectives on Social Change), PT Rineka Cipta, Jakarta.

Susanto, D. \& Djafar, Z. (1990). Perubahan Politik di Negara-negara Eropa Timur, Gramedia Pustaka Utama, Jakarta.

DPD Partai Golkar Kota Bandung, tt. Buku Saku Anggota Partai Golkar 2004-2009, Bandung.

DPP Golkar, 1998. Materi Penyegaran Kader Golongan Karya, Jakarta. 
Kompas, Monday edition, 13-12-2004, page. 4 article about Multiple Sclerosis di Tubuh Golkar (Muhammad Qodari), Kongres Partai Golkar 2004 (Jusuf Wanandi), and Desimplifikasi Partai Golkar (M. Alfan Alfian M.), Jakarta.

Kompas, Monday edition, 9-5-2005, page. 4, article about Dominasi Parpol dalam Pilkada: Menuju Terwujudnya Sistem Partai Kartel? (J. Kristiadi), Jakarta.

Kompas, Tuesday edition, 17-5-2005, page 4 about Tajuk Rencana Menjelang Pilkada Marak Konflik Warnawarni, Jakarta.

Kompas, Monday edition, 9-5-2006, page. 4 about Krisis Partai Pascapemilu Reformasi, Jakarta.

Kompas, Wednesday edition, 24-12-2008, page. C about Putusan Mahkamah Konstitusi mengenai Suara Terbanyak, Bandung.

Kompas, Wednesday edition, 21-01-2009, page. C about Putusan MK Panaskan Persaingan Internal, Bandung. Setjen DPP Golkar, (2000). Buku Saku Anggota Golkar 2000-2005, Jakarta. 